\title{
SURVEY OF MATERIALS, METHODS EMPLOYED, AND ATTITUDES TOWARDS INTERNATIONAL ENDODONTIC TREATMENT PROTOCOL STANDARDS BY GENERAL DENTAL PRACTITIONERS IN LITHUANIA. DOES AGE MATTER?
}

\author{
Linas Vaitkus ${ }^{1}$, Miglė Mackevičiūtè², Eduardas Kelbauskas ${ }^{2}$ \\ ${ }^{1}$ Lithunian University of Health Sciences, Faculty of Odontology, \\ ${ }^{2}$ Lithunian University of Health Sciences, Faculty of Odontology, \\ Department of Dental and Oral Pathology
}

Key words: general dentist, survey, endodontic treatment, root canal treatment, endodontic treatment requirements.
Summary
Aim.To acquire statistical data concerning the ma- terials, methods, and approaches used by general dentists in Lithuania, when treating teeth endodon- tically, while comparing said data with set treatment standards of undergraduate education to determine if practitioners' years of experience had influence on aforementioned factors.
Materials and Methods. In total, 350 surveys were dispersed among four major Lithuanian cities (Vil- nius, Kaunas, Klaipeda, Utena) to bring forth data. These questionnaires included questions concerning the participant's gender, experience in dentistry in years, materials and methods used, etc. Statistical analysis of the data was performed using SPSS 22.0 (Statistical Package for Social Science 22 for Win- dows)
Results. From the total, 134 (38.3\%) surveys were returned for analysis. Only those surveys were ana- lyzed which were fully filled and were from general dentists, who were performing endodontic treatment to their patients (109 or $31.1 \%$ ). Respondents who did not qualify to the set forth criteria were automati- cally removed from further analysis. $77.6 \%$ of youn- ger dentists (10 years or less in the field) preferred to use a rubber dam as an isolation material while only $30.6 \%$ of older generation specialists (more than 10 years in the field) performed endodontic treatment with it. Step back technique was more popular to

use for younger generation dentists while NiTi rotary system and Crown down (hand files) technique for the more experienced clinicians. Almost all respondents used K-files in root canal treatment, while the most popular time to take dental X-rays was detrmined to be before treatment and after root canal filling. Cold lateral condensation technique for root canal filling was the most popular choice, while the sealer type most often used was zinc oxide eugenol. Most commonly used root canal irrigation was sodium hypochlorite.

Conclusions. From the statistics brought forth from this study, it is apparent that younger generation of dentists follow the endodontic treatment regulations somewhat closer than the older generation, but not in all aspects of treatment.

\section{Introduction}

Incorrectly treated or untreated apical periodontitis is commonplace among the European population. Studies from countries of Europe have shown concreted evidence that the standard of root canal treatment which is provided by dentists is generally not satisfactory and even low. The need for improvement of the standard is obvious $[1,15]$. The positive result of a root canal system treatment has been identified to depend on: correct pre-treatment diagnosis of the tooth, maintenance of root canal sterility which is facilitated by a quality apical seal and a solid coronal restoration, use a of a rubber dam, the following of endodontic treatment protocol, hygienic/sterile environment in which the doctor works [1, 15]. It is a common belief that the success of endodontic treatment is largely dependent on the doctor performing the procedure. Even though here is not enough research perfor- 
Table 1. Questions comprising the survey used for this research

\begin{tabular}{|c|c|}
\hline Study variables / questions & Measurement scale / answers \\
\hline 1. Gender & (1) Male; (2) Female \\
\hline 2. Age & [Self-fill-in] \\
\hline 3. Years of dental practice & (1) $1-5$; (2) $6-10$; (3) $11-20$; (4) $20+$ \\
\hline $\begin{array}{r}\text { 4. Do you perform endodontic treatment for } \\
\text { your patients? }\end{array}$ & (1) Yes; (2) No \\
\hline $\begin{array}{r}5 . \text { If the answer to question } \# 4 \text { is no, what is } \\
\text { the reason? }\end{array}$ & $\begin{array}{l}\text { (1) Lack of time; (2) Lack of competence; (3) } \\
\text { Difficult and not worth financially; (4) Other } \\
\text { [self-fill-in] }\end{array}$ \\
\hline $\begin{array}{r}\text { 6. Do you undertake endodontic treatment } \\
\text { of molar teeth? }\end{array}$ & (1) Yes; (2) No \\
\hline $\begin{array}{l}\text { 7. What sorts of isolation methods/materials } \\
\text { you use when treating teeth endodontically? }\end{array}$ & $\begin{array}{l}\text { (1) Rubber dam system; (2) Only cotton } \\
\text { gauze; (3) Only large volume suction; (4) } \\
\text { Cotton gauze and large volume suction; (5) } \\
\text { None; (6) Other [self - fill-in] }\end{array}$ \\
\hline $\begin{array}{r}\text { 8. If the isolation method is a rubber dam } \\
\text { system, how often do you use it? }\end{array}$ & (1) Sometimes (rarely) (2) Always; \\
\hline $\begin{array}{r}\text { 9. What root canal cleaning and shaping } \\
\text { techniques do you use? }\end{array}$ & $\begin{array}{l}\text { (1) Step back technique; (2) Crown down } \\
\text { technique (hand instruments); (3) Nickel- } \\
\text { Titanium rotary system ; (4) Other [self - fill- } \\
\text { in] }\end{array}$ \\
\hline $\begin{array}{r}\text { 10. Which of the following files do you use } \\
\text { for root canal preparation? }\end{array}$ & $\begin{array}{l}\text { (1) K - files; (2) H - files [Hedstrom]; (3) } \\
\text { Reamers; (4) Nickel - Titanium hand files; (5) } \\
\text { Nickel - Titanium rotary system files; (6) } \\
\text { Other [self - fill-in] }\end{array}$ \\
\hline $\begin{array}{l}\text { 11. In which root canal treatment step do } \\
\text { you perform dental X-ray imaging? }\end{array}$ & $\begin{array}{l}\text { (1) Before starting the treatment; (2) Checking } \\
\text { of the working length with inserted file; (3) } \\
\text { Checking of master apical point; (4) After } \\
\text { obturation; (5) Never }\end{array}$ \\
\hline $\begin{array}{r}\text { 12. Which of the following root canal } \\
\text { irrigants do you use? }\end{array}$ & $\begin{array}{l}\text { (1) Sodium hypochlorite; (2) Chlorhexidine; } \\
\text { (3) Physiological solution; (4) Hydrogen } \\
\text { peroxide; (5) Citric acid; (6) A combination of } \\
\text { many [self - fill-in]; (7) None; (8) Other [self } \\
\text { - fill - in] }\end{array}$ \\
\hline $\begin{array}{r}\text { 13. If you chose sodium hypochlorite as one } \\
\text { of the irrigants, what concentration do you } \\
\text { use? }\end{array}$ & [self-fill-in] \\
\hline
\end{tabular}

med, it is very relevant for doctors and for the shaping of public opinion. Increasingly more popular is the publication of articles observing the close association between the endodontic procedure success and the dentists performing the treatment $[2,3]$. It is important to understand how doctors with different clinical experience lengths can affect the endodontic treatment performed, as well as when and how their effects can manifest. General dental practitioners who completed studies earlier than 10 years ago, are more prone to apply innovations in their clinical practice (rubber dam system, the use of rotary instruments and electronic apex locators) than their older colleagues who graduated more than 10 years ago [4]. Because of this, it is safe to assume that the integration of innovations in the clinical field of practice improves the quality of the procedures performed. However, the undertaking of difficult clinical cases is still more prominent by more experienced clinicians than by recent graduates or doctors with few years of experience [4].

The aim of this research was to acquire results from general dentists of various career lengths via a questionnaire, and to compare the acquired data to established treatment standards. The hypothesis is that the more recently graduated dentists follow endodontic protocol more and a trend is seen in that as experience in the field (in years) increases the abidance to the protocol wavers.

\begin{tabular}{|c|c|}
\hline $\begin{array}{r}\text { 14. If you chose sodium hydrogen peroxide } \\
\text { as one of the irrigants, what concentration } \\
\text { do you use? }\end{array}$ & [self - fill - in] \\
\hline $\begin{array}{r}\text { 15. What kind of intracanal medications do } \\
\text { you use? }\end{array}$ & $\begin{array}{l}\text { (1) Calcium hydroxide; (2) Calcium hydroxide } \\
\text { + iodoform; (3) Eugenol; (4) Formocresol; (5) } \\
\text { None; (6) Other [self - fill -in] }\end{array}$ \\
\hline $\begin{array}{r}\text { 16. What kind of material (s) do you use for } \\
\text { Root canal obturation? }\end{array}$ & $\begin{array}{l}\text { (1) Gutta - percha; (2) Cement [self-fill-in]; } \\
\text { (3) Paste [self - fill - in]; (4) Silver points; (5) } \\
\text { Other [self - fill - in] }\end{array}$ \\
\hline $\begin{array}{l}\text { 17. What gutta-percha obtwration } \\
\text { technique do you use? }\end{array}$ & $\begin{array}{l}\text { (1) Single cone; (2) Lateral condensation; (3) } \\
\text { Vertical condensation; (4) Hot vertical } \\
\text { modified condensation; (5) Thermafil; (6) } \\
\text { Other [self-fill-in] }\end{array}$ \\
\hline 18. What type of sealer do you use? & $\begin{array}{l}\text { (1) Zinc oxide eugenol based sealer; (2) } \\
\text { Calcium based sealer; (3) Silicone based } \\
\text { sealer; (4) Resin based sealer; (5) MTA based } \\
\text { sealer; (6) Other [self }- \text { fill }- \text { in] }\end{array}$ \\
\hline $\begin{array}{r}\text { 19. What temporary filling do you use } \\
\text { between appointments when performing } \\
\text { root canal treatment? }\end{array}$ & $\begin{array}{l}\text { (1) Zinc oxide eugenol filling; (2) Glass } \\
\text { ionomer; (3) Inter appointment filling (ex: } \\
\text { Cavit) (4) Other [self - fill - in] }\end{array}$ \\
\hline $\begin{array}{l}\text { 20. In how many visits, on average, do you } \\
\text { finish endodontic treatment of single- } \\
\text { canaled teeth (initial treatment)? }\end{array}$ & [self - fill - in] \\
\hline $\begin{array}{l}\text { 21. In how many visits, on average, do you } \\
\text { finish endodontic treatment of double- } \\
\text { canaled teeth (initial treatment)? }\end{array}$ & [self - fill - in] \\
\hline $\begin{array}{l}\text { 22. In how many visits, on average, do you } \\
\text { finish endodontic treatment of multi- } \\
\text { canaled teeth (initial treatment)? }\end{array}$ & [self- fill-in] \\
\hline $\begin{array}{l}\text { 23. After the completion of root canal } \\
\text { treatment, do you do a follow- } u \text { X-ray? }\end{array}$ & (1) Yes; (2) No \\
\hline $\begin{array}{r}\text { 24. If the answer to question } \# 23 \text { is } Y E S \text {, } \\
\text { how often do you perform a follow-up } X \text { - } \\
\text { ray? }\end{array}$ & $\begin{array}{l}\text { (1) } 3 \text { months ; (2) } 6 \text { months ; (3) } 12 \text { months ; } \\
\text { (4) More than } 1 \text { year but less than } 2 \text {; (5) } 2-3 \\
\text { years; (7) Other [ [self - fill - in] }\end{array}$ \\
\hline $\begin{array}{r}25 . \text { If the answer to question number } \# 23 \text { is } \\
\text { NO, what is the reason? }\end{array}$ & $\begin{array}{l}\text { (1) If there is no complaints/symptoms; (2) } \\
\text { Don't see the need; (3) Additional exposure to } \\
\text { radiation and X-ray imaging expenses; (4) } \\
\text { Other [self - fill - in] }\end{array}$ \\
\hline $\begin{array}{r}\text { 26. When do you send the patient to an } \\
\text { endodontic specialist? }\end{array}$ & $\begin{array}{l}\text { (1) Very difficult clinical cases ; (2) Root } \\
\text { canal retreatment; (3) On demand of the } \\
\text { patient ; (4) Other [self - fill - in] }\end{array}$ \\
\hline
\end{tabular}

\section{Materials and methods}

Due to financial limitations and sheer size of registered dental practitioners, four cities in Lithuania were selected to gather data. Cities were selected on their population size and ability of the surveyor to acquire results efficiently. The questionnaire was answered by a wide range of specialists, the youngest responded being 23 years while the oldest 69 years of age. The structured survey was comprised of 26 questions containing multiple - choice answers where a responded could checkmark either one or more than one answer, as well as write in their own answer (where possible). The survey was comprised of questions concerning gender, professional career length in years, willingness to undertake endodontic molar teeth treatment, if endodontic root canal treatment procedures were performed including the use of a rubber dam and if so, how persistently it was used, details about performing rentgenological checking and when this checking is performed, choice of instruments and root canal irrigants and their corresponding concentrations, use of intracanal medications, choice of an obturation technique and sealer type, type of temporary filling used, approximate number of visits for treatment of different teeth, if the tooth is followed rentgenologically and for how long, and when 
Table 2. Sorts of isolation materials and how often they are used $\chi^{2}=$ Chi square, OR - Odds ratio, CI - Confidence Interval.

\begin{tabular}{|c|c|c|c|c|}
\hline $\begin{array}{l}\text { What sorts of isolation methods/ } \\
\text { materials you use when treating } \\
\text { teeth endodontically? }\end{array}$ & $\begin{array}{l}A \\
(n=46)\end{array}$ & $\begin{array}{l}B \\
(n=13)\end{array}$ & $\begin{array}{l}\text { C } \\
(n=13)\end{array}$ & $\begin{array}{l}D \\
(n=37)\end{array}$ \\
\hline \multirow[t]{3}{*}{ Rubber dam system } & 36 & 10 & 5 & 8 \\
\hline & \begin{tabular}{|l|}
78.3 \\
13.05 \\
{$[4.565-37.31]$}
\end{tabular} & $\begin{array}{l}76.9 \\
12.083 \\
{[2.672-54.647]}\end{array}$ & \begin{tabular}{|l|}
38.5 \\
2.266 \\
{$[0.579-8.865]$}
\end{tabular} & $\begin{array}{l}21.6 \\
1\end{array}$ \\
\hline & \multicolumn{4}{|c|}{$\chi^{2}=30.541, \mathrm{df}-3, \mathrm{p}=0.001$} \\
\hline \multirow[t]{3}{*}{ Cotton gauze } & 2 & 0 & 1 & 6 \\
\hline & 4.3 & 0.00 & 7.7 & 16.2 \\
\hline & \multicolumn{4}{|c|}{$\chi^{2}=5.198, \mathrm{df}-3, \mathrm{p}=0.158$} \\
\hline \multirow[t]{3}{*}{ Large volume suction } & 2 & 0 & 0 & 2 \\
\hline & 4.3 & 0.00 & 0.00 & 5.4 \\
\hline & \multicolumn{4}{|c|}{$\chi^{2}=1.366, \mathrm{df}-3, \mathrm{p}=0.714$} \\
\hline $\begin{array}{l}\text { Cotton gauze and large volume } \\
\text { suction }\end{array}$ & 35 & 11 & 12 & 32 \\
\hline \multirow[t]{2}{*}{$\%$} & 76.1 & 84.6 & 92.3 & 86.5 \\
\hline & \multicolumn{4}{|c|}{$\chi^{2}=2.632, \mathrm{df}-3, \mathrm{p}=0.452$} \\
\hline
\end{tabular}

Table 3. Root canal cleaning and shaping technique popularity $\chi^{2}=$ Chi square, $O R-$ Odds ratio, $C I-$ Confidence Interval

\begin{tabular}{|c|c|c|c|c|}
\hline $\begin{array}{l}\text { What root canal cle- } \\
\text { aning and shaping } \\
\text { techniques do you use? }\end{array}$ & $\mathrm{A}$ & B & $\mathrm{C}$ & $\mathrm{D}$ \\
\hline Step-back technique & 33 & 7 & 5 & 16 \\
\hline $\begin{array}{r}\% \\
\text { OR } \\
{[95 \% \mathrm{CI}]}\end{array}$ & $\begin{array}{l}71.7 \\
3.332 \\
{[1.336-} \\
8.308]\end{array}$ & $\begin{array}{l}53.8 \\
1.531 \\
{[.430-} \\
5.451]\end{array}$ & $\begin{array}{l}38.5 \\
.820 \\
{[.225-} \\
2.989]\end{array}$ & $\begin{array}{l}43.2 \\
1\end{array}$ \\
\hline & \multicolumn{4}{|c|}{$\chi^{2}=8.714, \mathrm{df}-3, \mathrm{p}=0.033$} \\
\hline $\begin{array}{l}\text { Crown down technique } \\
\text { (hand files) }\end{array}$ & 6 & 3 & 3 & 18 \\
\hline \multirow[t]{2}{*}{$\begin{array}{r}\% \\
\text { OR } \\
{[95 \% \mathrm{CI}]}\end{array}$} & $\begin{array}{l}13.0 \\
.158 \\
{[.054-} \\
.463]\end{array}$ & $\begin{array}{l}23.1 \\
.317 \\
{[.075-} \\
1.340]\end{array}$ & $\begin{array}{l}23.1 \\
.317 \\
{[.075-} \\
1.340]\end{array}$ & $\begin{array}{l}48.6 \% \\
1\end{array}$ \\
\hline & \multicolumn{4}{|c|}{$\chi^{2}=13.370$, df $-3, p=0.004$} \\
\hline $\begin{array}{l}\text { Nickel-Titanium rotary } \\
\text { system }\end{array}$ & 25 & 9 & 7 & 16 \\
\hline$\%$ & 54.3 & 69.2 & 53.8 & 43.2 \\
\hline & \multicolumn{4}{|c|}{$\chi^{2}=2.800, d f-3, p=0.423$} \\
\hline
\end{tabular}

is the patient sent to a endodontic specialist for treatment (Table 1). Only fully completed questionnaires who were filled out by general dentists were assessed. Surveys from specialists of endodontic treatment were not reviewed. For this study to be more concise and clear, respondents were divided into four groups (A, $\mathrm{B}, \mathrm{C}$, and D) in accordance to their duration of practice in the field of dentistry. Group A - 1-5 years; group $\mathrm{B}-6-10$ years; group $\mathrm{C}-11-20$ years; and group $\mathrm{D}$
$-20+$ years, and if the dentist performed endodontic treatment on their patients. If the doctor did not, the survey was removed from further assessment. Returned forms were first re-checked for full responses by a single operator, then tally-counted three times for consistency. Not fully answered questionnaires with a majority of blank answers were not analysed. Data was entered into a personal computer using Microsoft Excel 2013 (version: 15.0.4919.1000, 64-bit) spreadsheet for data accumulation and storage in preparation for statistical analysis.

Statistics. Statistical analysis of the data was performed using SPSS 22.0 (Statistical Package for Social Science 22 for Windows). All parametric data are expressed as the mean and SD (standard deviation). Binary logistic regression analysis was performed to determine odds ratio and $95 \%$ confidence interval. Differences between groups were considered significant when the level of significance $\mathrm{P}$ was less than $\mathrm{P}<0.05$.

\section{Results}

Out of the 350 questionnaires which were handed out via seminars, symposiums, and private meetings, 134 were returned for review and analysis. The rate of response was $38.3 \%$. From the 134 questionnaires, $18(13.4 \%)$ were not fully answered and $7(5.2 \%)$ respondents did not perform endodontic treatment for their patients. The remaining 109 responses $(31.1 \%)$ were further analysed and determined that 9 respondents $(9.0 \%)$ were male and the other $100(91 \%)$ were female. The mean age of the respondents was 39 years while the range was 23-69 years. To systematically organize the responses, four study groups, according to years in practice, were formed and distributed as follows: group A composed of 46 respondents (42.2\%), group B of 13 (11.9\%), group C of 13 (11.9\%) and group D of 37 (33.9\%). Responses to groups were allocated as follows: Group A 1-5 years in practice, group B 6-10 years in practice, group C 11-20 years in practice, and group D 20+ years in practice.

Isolation. The majority of younger general dental practitioners (Groups A and B) used rubber dam system as an isolation method as opposed to their older colleagues (Table 2). Statistical significance was observed in Groups A and B $(p<0.05)$. The groups reported using a rubber dam system with $78.3 \%$ and $76.9 \%$ respectively. On the other hand, group $\mathrm{C}$ answered positively at $38.5 \%$ and group D with a meager $21.6 \%$. The frequency of use of the rubber dam was also recorded with the results being that the rubber dam, among the groups, was used only sometimes, with no statistical significance $(\mathrm{p}>0.05)$. Answer of always using rubber 
dam was only $27 \%$, on average, among the groups. To much dismay, $83.8 \%$ respondents from group $\mathrm{D}$, clinicians with the most experience year-wise, did not use a rubber dam system and instead had a staggering $86.5 \%$ use of cotton gauze and high volume suction as the isolation of choice, while having one respondent use no isolation material at all. Interestingly, two respondents, one from group B the other from D, mentioned using OptraGate (Ivoclar Vivadent) and Dry Tips (Microbrush International) respectively as materials used for isolation while performing endodontic treatment for patients.

Chemo-mechanical preparation. The results for the type of technique for canal instrumentation were mixed and across the board. Group A most sought-after technique was, naturally, step back (71.7\%) with statistical significance recorded $(\mathrm{p}<0.05)$ (Table 3$)$. Furthermore, statistical significance in group A was observed as well with the crown down technique $(\mathrm{p}<0.05)$. NiTi rotary system was second most popular choice, with the exception in group A. Apical box technique was mentioned as other option by two respondents, one from group A the other from group D.

During root canal cleaning and shaping the most popular instrument of choice was determined to be the K-file. The reamer was the least used instrument among respondents from group A (10.9\%), group B and C (23.1\%), while group D participants $(45.9 \%)$ used it regularly, showing a tendency of different preference among the younger and older generation of dentists. Similar observation can be made with the H-file. Only $17.4 \%$ of respondents from group A used it, placing it as

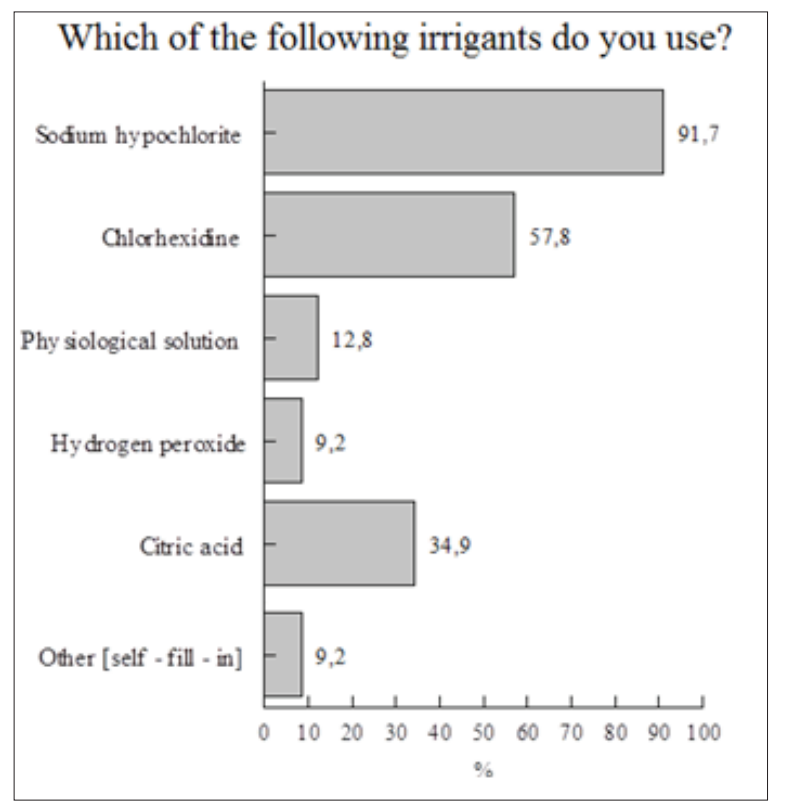

Fig. 1. Bar chart showing most popular intracanal irrigation solutions the second least used file among the group (after the reamer) while group D used the H-file quite often at $56.8 \%$ of respondents reporting using it . Nickel -titanium rotary instruments had no statistical significance among the groups $(\mathrm{p}>0.05)$.

Irrigation and intracanal medications used. The use of irrigants while treating teeth endodontically is essential to provide lubrication for the glide path as well as disinfection and was reported to be used by all respondents. The most common choice reported was sodium hypochlorite (Fig. 1). No statistical significance was recorded ( $p>0.05)$. The concentrations of sodium hypochlorite were reported as $2.5 \%$ most popular in groups A and B, while 5.25 in groups $\mathrm{C}$ and D. No statistical significance was recorded $(\mathrm{p}>0.05)$.

Table 4. Intracanal medications used for endodontic purposes $\chi^{2}=$ Chi square

\begin{tabular}{|l|l|l|l|l|}
\hline $\begin{array}{l}\text { What kind of intracanal medi- } \\
\text { cations do you use? }\end{array}$ & A & B & C & D \\
\hline Calcium hydroxide & 45 & 13 & 13 & 37 \\
\hline & 97.8 & 100 & 100 & 100 \\
\hline & $\chi^{2}=30.541, \mathrm{df}-3, \mathrm{p}=0.74$ \\
\hline Calcium hydroxide + iodoform & 27 & 8 & 9 & 19 \\
\hline$\%$ & 58.7 & 61.5 & 69.2 & 51.4 \\
\hline & $\chi^{2}=1.417, \mathrm{df}-3, \mathrm{p}=0.702$ \\
\hline Eugenol & 27 & 5 & 5 & 13 \\
\hline & 58.7 & 38.5 & 38.5 & 35.1 \\
\hline & $\chi 2=5.339, \mathrm{df}-3, \mathrm{p}=0.149$ \\
\hline Formocresol & 9 & 2 & 2 & 9 \\
\hline & 19.6 & 15.4 & 15.4 & 24.3 \\
\hline & $\chi^{2}=.776, \mathrm{df}-3, \mathrm{p}=0.855$ \\
\hline
\end{tabular}

Table 5. Root canal obturation materials

\begin{tabular}{|c|c|c|c|c|}
\hline $\begin{array}{l}\text { What kind of material(s) } \\
\text { do you use for root canal } \\
\text { obturation? }\end{array}$ & A & B & $\mathrm{C}$ & $\mathrm{D}$ \\
\hline Gutta-percha & 46 & 13 & 13 & 37 \\
\hline$\%$ & 100.0 & 100.0 & 100.0 & 100.0 \\
\hline Cement [self-fill-in] & 4 & 1 & 1 & 1 \\
\hline$\%$ & 8.7 & 7.7 & 7.7 & 14.3 \\
\hline & \multicolumn{4}{|c|}{$\chi^{2}=1.317, \mathrm{df}-3, \mathrm{p}=0.725$} \\
\hline Paste [self - fill - in] & 5 & 1 & 1 & 5 \\
\hline \multirow[t]{2}{*}{$\%$} & 10.9 & 7.7 & 7.7 & 13.5 \\
\hline & \multicolumn{4}{|c|}{$\chi^{2}=.530, \mathrm{df}-3, p=0.912$} \\
\hline \multirow[t]{3}{*}{ Silver points } & 0 & 0 & 0 & 1 \\
\hline & 0.0 & 0.0 & 0.0 & 2.7 \\
\hline & \multicolumn{4}{|c|}{$\chi^{2}=1.964, \mathrm{df}-3, p=0.580$} \\
\hline \multirow[t]{2}{*}{ Other [self - fill - in] } & 0 & 0 & 0 & 1 \\
\hline & 0.0 & 0.0 & 0.0 & $2 . .7$ \\
\hline$\%$ & \multicolumn{4}{|c|}{$\chi^{2}=1.964, \mathrm{df}-3, \mathrm{p}=0.580$} \\
\hline
\end{tabular}


Chlorhexidine was the second most popular choice among the four groups with citric acid being the third. Hydrogen peroxide was among the least used irrigant with only one respondent (2.17\%) from group A using it, two (15.38\%) from group $\mathrm{B}$, none from group $\mathrm{C}$ and $24.32 \%$ from group $\mathrm{D}$ with the concentrations being $1 \%$ in groups $\mathrm{A}$ and $\mathrm{B}$, while $3 \%$ in group D. EDTA was mentioned by all groups as other choice of irrigant, while also mentioning it as a combination irrigant with distilled water in groups A, B and D.

Not surprisingly, most popular intracanal medication among the four study groups was calcium hydroxide. No statistical significance $(p>0.05)$ was recorded among the groups for any of the intracanal medications (Table 4). Formacresol was used the least among the specialist groups, group A reporting at $19.6 \%$, group B and C $15.4 \%$, and group D $27.03 \%$. This is probably due to the fact that formacresol is mainly used for paediatric endodontic treatment. To note, three respondents from group A mentioned using triple antibiotic paste in root canal therapy which is somewhat of a new, promising treatment option.

Obturation techniques and materials. Complete and quality obturation is essential for the long term prognosis of a tooth which is endodontically treated. Among the respondents, gutta-percha was the most common material for canal obturation, with all respondents from all groups using it (Table 5).

Lateral condensation was the most common obturation

Table 6. X-ray imaging preferences

\begin{tabular}{|c|c|c|c|c|}
\hline $\begin{array}{l}\text { In which root canal treat- } \\
\text { ment step do you perform } \\
\text { dental X-ray imaging? }\end{array}$ & $\mathbf{A}$ & B & $\mathbf{C}$ & D \\
\hline $\begin{array}{l}\text { Before starting the treat- } \\
\text { ment }\end{array}$ & 40 & 12 & 12 & 33 \\
\hline$\%$ & 87.0 & 92.3 & 92.3 & 89.2 \\
\hline & \multicolumn{4}{|c|}{$\chi^{2}=.488 \mathrm{df}-3, \mathrm{p}=0.922$} \\
\hline $\begin{array}{l}\text { Checking of the working } \\
\text { length with inserted file }\end{array}$ & 27 & 7 & 9 & 22 \\
\hline \multirow[t]{2}{*}{$\%$} & 58.7 & 53.8 & 69.2 & 59.5 \\
\hline & \multicolumn{4}{|c|}{$\chi^{2}=.696 \mathrm{df}-3, \mathrm{p}=0.874$} \\
\hline \multirow{3}{*}{$\begin{array}{r}\begin{array}{l}\text { Checking of master apical } \\
\text { point }\end{array} \\
\% \\
\text { OR } \\
{[95 \% \mathrm{CI}]}\end{array}$} & 35 & 8 & 9 & 15 \\
\hline & $\begin{array}{l}76.1 \\
4.667 \\
{[1.817-} \\
11.985]\end{array}$ & $\begin{array}{l}61.5 \\
2.347 \\
{[.642-8.575]}\end{array}$ & \begin{tabular}{|l|}
69.2 \\
3.300 \\
{$[.857-12.708]$}
\end{tabular} & \begin{tabular}{|l}
40.5 \\
1
\end{tabular} \\
\hline & \multicolumn{4}{|c|}{$\chi^{2}=11.323 \mathrm{df}-3, \mathrm{p}=0.010$} \\
\hline After obturation & 37 & 9 & 10 & 19 \\
\hline $\begin{array}{r}\% \\
\text { OR } \\
{[95 \% \mathrm{CI}]}\end{array}$ & $\begin{array}{l}80.4 \\
3.895 \\
{[1.427-} \\
10.302\end{array}$ & $\begin{array}{l}69.2 \\
2.132 \\
{[.557-8.162]}\end{array}$ & \begin{tabular}{|l|}
76.9 \\
3.158 \\
{$[.746-13.359]$}
\end{tabular} & \begin{tabular}{|l|}
51.4 \\
1
\end{tabular} \\
\hline & \multicolumn{4}{|c|}{$\chi 2=8.551 \mathrm{df}-3, \mathrm{p}=0.036$} \\
\hline
\end{tabular}

technique used among the groups with $91.7 \%$ of clinicians reporting using it, with no statistical significance recorded. Only $7.3 \%$ of respondents reported using vertical condensation technique. None of the respondents answered using Thermafil as an obturation technique, while single-gutta technique was used limitedly among the groups with only a $16.5 \%$ reported use.

Good sealing ability of a material is mandatory in endodontics to obtain a satisfactory result. Zinc oxide eugenol based sealer was the most commonly used within the groups at $64.7 \%$. Resin-based sealers were not as popular, yet still $37.6 \%$ of respondents reporting using it. No statistical significance reported among the groups for any of the sealers.

Performing X-ray examination. When asked about the time of X-ray check-up, responses varied across all four groups, but general consensus was before treatment, with $87.0 \%$ of respondents from group A, $92.3 \%$ from group B and $\mathrm{C}$, and $89.2 \%$ from group D (Table 6). Statistical significance was observed in group A for checking of master apical point $(\mathrm{p}<0.05)$ and after obturation $(\mathrm{p}<0.05)$. Notably, only $40.5 \%$ of group D participants performed X-ray control for working length verification, and slightly more than half (51.4\%) performed an X-ray after obturation.

Questions about follow-up X-rays were also asked of the respondents, and a positive response was received from $43.5 \%$ of group A participants, $46.2 \%$ from group B, $76.9 \%$ from group C, and $35.1 \%$ from group D. Most of the aforementioned respondents answered performing a followup X - ray every 6 months with no statistical significance observed. The ones that answered that they do not perform a follow-up, the main reason was that the patient does not have complaints.

Number of visits. Participants of this study were asked how many visits, on average, it takes them to complete treatment for certain types of teeth. Statistical significance was observed in groups $C(p<0.05)$ and $D(p<0.05)$ in treatment of single - canaled teeth. Statistical significance was also recorded for double-canaled teeth between groups B, C $(p<0.05)$, and D $(p<0.05)$. It took clinicians among the four groups a little over two visits, to complete double canaled teeth. Statistical significance was found in groups A and D $(\mathrm{p}=0.037)$ and group $\mathrm{C}(\mathrm{p}<0.05)$ when analysing how many visits it took general dental practitioners to treat multi-canaled teeth, which was determined to be almost three, on average of all four of the groups.

Referral patterns. Most referrals to a specialist happened due to a very difficult case, with statistical significance recorded ( $p<0.05$ ). $40.5 \%$ of Group D respondents referred a patient to a specialist when the patient asked to be treated by one with statistical significance recoded at $(p<0.05)$. 


\section{Discussion}

A study performed by V. Peciuliene et al. (2010) was a similar study to the present one, but did not study the radiographic preferences, referral patterns, or delve deeper into the differences of preferences among the younger and older generation of dentists [6]. It is also important to ascertain what has changed during the last seven years.

From the presented study, it was possible to assess the methods and attitudes employed by broad age, and different generations of general dental practitioners of Lithuania, in the treatment of teeth endodontically. Broadly, dentists of all age groups did not follow standards of root canal treatment, although the younger generation was determined to be more inclined to pursue the set forth regulations. Due to a small sample size, only an approximation of all dentists of Lithuania could be performed and a concrete conclusion about the whole general dental professionals' population cannot be drawn. Adjustment in the educational field as well as quality control is in order, to prepare and strengthen the younger generation for the work field, as well as maintain standards for the older generation, so as to lessen the frequency of apical periodontitis in endodontically treated teeth of the people of Lithuania.

The use of surveys to collect data for analysis among populations is a prevalent instrument among the scientific community $[6,12,13,14]$. Among disadvantages such as false answers and human error, the most considerable one in collection of information from questionnaire is the lack of responses among populations in question. This study is no exception, with the response rate of $38.3 \%$ and the actual usable data being only $31.1 \%$ of all the questionnaires. This can be seen with questionnaires conducted by more notable persons in scientific field and bigger populations of study thus showing no correlation to either factor $[10,11]$. Nevertheless, a questionnaire, such as the one presented, guarantees anonymity, is presented in a standardized method, is relatively an economic way to acquire results, and requires little to no assistance to the operator.

The isolation of teeth with a rubber dam when treating endodontically is a must, and plain gauze and suction is not enough [15]. Nonetheless, the use of a rubber dam by general dentists shows that it is not a 'golden rule' followed by all. $38 \%$ of Irish general practitioners mentioned rarely or even never using a rubber dam while treating a molar tooth endodontically. For other types of teeth the percentages were even higher [5]. A similar trend was noticed in north-west England with only $30 \%$ of respondents ever using a rubber dam [16]. Even worse case was reported in Turkey, with only $5.1 \%$ dentists using a rubber dam with number of years of professional activity not affecting isolation preference [9].
Similar, though less bleak, results were acquired with this study. Even though $78.3 \%$ and $76.9 \%$ of group A and B respectively used a rubber dam, versus $38.5 \%$ and $21.6 \%$ from groups $\mathrm{C}$ and $\mathrm{D}$, the percentages for always using rubber dam while treating teeth endodontically were significantly lower among all four groups. $27.0 \%$ was the average of all four groups using a rubber dam always.

The use of a radiography in root canal therapy is another essential element in every day working conditions of dentists. A study conducted in United Kingdom, showed that 83.9\% of general practitioners took preoperative X-rays, and $86.7 \%$ took post-operative ones as well. However, $69.5 \%$ performed working length checking X-ray, and only $35 \%$ checked the cone fit [17]. A questionnaire regarding the application of quality guidelines of the European society of endodontology in Poland reported similar results with 45.4\% GDP reporting occasionally using X-rays for apex location determination, and $21.6 \%$ reporting to never using [7]. Surpassing results were acquired from Lithuanian dentists in a study concerning the use of dental radiography among Lithuanian general dentists. This research concluded that, "Of all respondents $91.5 \%$ used radiography always or often during the diagnostic procedures. Younger respondents more often used radiography as diagnostic tool than their older counterparts" [12]. Similar, yet more precise, results were acquired from the present study, showing that on average, $90.2 \%$ dentists performed X - rays before treatment, and $69.5 \%$ performing X-ray examination post-op. Tendency of a substantial number of younger practitioners to perform radiography after treatment than before versus older practitioners performing X-rays before than after was observed.

Not all cases can be treated quickly or by general dental practitioners alone, and so referrals to specialists occur. Studies show that endodontic treatment by most general dental practitioners, on average, is to be completed in two visits $[7,11]$. Similar results were obtained with the present study, with the majority respondents answering to completing endodontic treatment in approximately two visits, with multi-canaled teeth requiring a bit more time. Furthermore, it was determined that the main two reasons for referrals were difficult clinical cases and retreatment cases. Comparable results were acquired from another, alike study where $79 \%$ of respondents referred patients when there were difficult diagnostics, and $86.6 \%$ mentioned referring due to complication like fractured instrument [13]. Only 31.7\% of GDP's did complex endodontic treatment while 50.9\% would undertake endodontic retreatment, determined the treatment procedures and referral patterns of general dentists in Lithuania clinical study [18].

Quality mechanical preparation and instrumentation is 
one of the main, if not the main step affecting the end result of endodontic treatment. Proper removal of layers of affected dentine in walls in the root canal is and always has been the main goal of successful instrumentation [25]. With the increased acceptance and usage of nickel-titanium files, rotary or handheld, studies have shown time and time again the increased effectiveness and usage speed over regular, more traditional approaches such as using K-files, $\mathrm{H}$-files, or reamers $[19,20]$. Having said that, the popular use of date instruments still persists. A study conducted in Denmark noted that only $10 \%$ of general dental practitioners used rotary nickel-titanium instruments [21]. A further observation could be made that the younger generation used step back technique more often that the older, where the aforementioned technique uses mainly only K-files [8]. Comparable results were acquired in the present study whereas the professionals age, the step back technique fades out in usage and the usage of rotary system becomes more prominent. To accompany and compliment a quality root canal instrumentation, copious antimicrobial irrigation is needed. Various studies have shown that sodium hypochlorite, with its ample disinfecting properties is the most popular choice among general dentists $[10,22$, and 23]. In the Serbian study, it was determined that $2.5 \%$ concentration was most popular among GDP's, while in the German one $-3 \%$. The study at hand revealed that the most popular concentration was $2.5 \%$ for younger practitioners and $5.25 \%$ for the more experienced ones. Since it was determined that single visit treatment was very rare, intracanal medicaments are placed for the interappointment time. In this present study, an almost unanimous, across the groups decision was observed to use calcium hydroxide as the medicament of choice, with the lowest usage reported at $97.8 \%$. Similar results were seen in a study from Sweden with usage of calcium hydroxide at 90\% [19]. However the use of calcium hydroxide as interappointment medicament was only $53 \%$ in a study from Turkey, suggesting closer similarity of Lithuanian dentists to northern Europe than southern [9].

Finally, the obturation materials and techniques employed play the other essential part of root canal treatment [26]. This study concluded that lateral condensation was the most used technique for root canal obturation. The cold-lateral condensation of gutta-percha points, in conjunction with a root canal sealer, is the most widely accepted technique for obturating root canals and is the technique taught in most dental schools as part of their undergraduate program $[5,20]$. Furthermore, it was analysed that zinc oxide eugenol based sealers were the sealers of choice with the use of gutta-percha points. Zinc oxide eugenol based sealers, even though being popular, are not the best choice as other sealers offer better results [24].
It may be impossible to reliably fill the root canal space in three-dimensions with the single-cone/point gutta-percha technique. Therefore this treatment modality is not recommended as a standard endodontic treatment $[13,16]$. With paste-type root fillings, the risk of underfilling or overfilling of the root canal is obvious. Nevertheless, on average, 9.9\% of respondents answered using paste-type fillings for obturation of canals, in the present study.

\section{Conclusion}

Overall, complete abidance of endodontic protocol was not followed by dental practitioners participating in this survey. Younger, less experienced dentists followed the endodontic protocol in part closer than their more experienced, older colleagues.

\section{Acknowledgement}

This research was made possible by all those who actively participated in the research.

\section{Conflict of interests}

The author has not encountered any conflicts of interests.

\section{References}

1. Gatley S, Hayes J, Davies C. Requirements in terms of root canal treatment of undergraduates in the European Union: an audit of teaching practice. British Dental Journal 2009; 207:165-170. https://doi.org/10.1038/sj.bdj.2009.716

2. Mandel E, Adib-Yazdi M, Benhamou LM, Lachkar T, Mesgouez C, Sobel M. Rotary Ni-Ti profile systems for preparing curved canals in resin blocks: influence of operator on instrument breakage. International Endodontic Journal 1999; 32(6):436-43. https://doi.org/10.1046/j.1365-2591.1999.00239.x

3. Mu-oz E, Forner L, Llena C. Influence of operator's experience on root canal shaping ability with a rotary nickel - titanium single - file reciprocating motion system. Journal of Endodontics 2014; 40(4):547-50.

https://doi.org/10.1016/j.joen.2013.08.027

4. Savani G, Sabbah W, Sedgley C, Whitten B. Current trends in endodontic treatment by general dental practitioners: report of a United States national survey. Journal of Endodontics 2014; 40(5):618-24.

https://doi.org/10.1016/j.joen.2014.01.029

5. Lynch C, McConnell R. Attitudes and use of rubber dam by Irish general dental practitioners. International Endodontic Journal 2007; 40:427-432.

https://doi.org/10.1111/j.1365-2591.2007.01212.x

6. Peciuliene V, Rimkuviene J, Aleksejuniene J, Haapasalo M, Drukteinis S, Maneliene R. Technical aspects of endodontic treatment procedures among Lithuanian general dental practitioners. Baltic Dental and Maxillofacial Journal 2010; 12:42-50. 
7. Slowik J, Jurczak A, Zarow M. The application of quality guidelines of the European society of endodontology in dental practice in Poland. Annales Academiae Medicae Stetinensis 2011; 57(1): 110-115.

8. Kaptan R, Haznedaroglu F, Kayahan M, Basturk F. An Investigation of Current Endodontic Practice in Turkey. The Scientific World Journal 2012; Article ID 565413, 6 pages.

9. Unal G, Kaya B, Tac A, Kececil A. Survey of attitudes, materials and methods preferred in root canal therapy by general dental practice in Turkey: Part 1. European Journal of Dentistry 2012; 6(4):376-384.

10. Willershausen I, Wolf T, Schmidtmann I, Berger C, Ehlers V, Willershausen B, Brise-o B. Survey of root canal irrigating solutions used in dental practices within Germany. International Endodontic Journal 2015; 48(7):654-60.

https://doi.org/10.1111/iej.12360

11. Slaus G, Bottenberg P. A survey of endodontic practice amongst Flemish dentists. International Endodontic Journal 2002; 35:75-767.

https://doi.org/10.1046/j.1365-2591.2002.00564.x

12. V. Peciuliene, J. Rimkuviene, R. Maneliene, S. Drukteinis. Use of dental radiography among Lithuanian general dentists. Baltic Dental and Maxillofacial Journal 2009; 11:77-82.

13. Peciuliene V, Rimkuviene J, Maneliene R, Drukteinis S. The need and reasons for referrals to specialists among Lithuanian general dentists. Medicina (Kaunas) 2010; 46(9):611-5.

14. Skucaite N, Peciuliene V, Maneliene R, Maciulskiene V. Antibiotic prescription for the treatment of endodontic pathology: a survey among Lithuanian dentists. Medicina (Kaunas) 2010; 46(12):806-13.

15. European Society of Endodontology. Quality guidelines for endodontic treatment: consensus report of the European Society of Endodontology. International Endodontic Journal 2006; 39:921-930.

https://doi.org/10.1111/j.1365-2591.2006.01180.x

16. Palmer N, Ahmed M, Grieveson B. An investigation of current endodontic practice and training needs in primary care in the north west of England. British Dental Journal 2009; 206(11):584-5.

https://doi.org/10.1038/sj.bdj.2009.473

17. Orafil I, Rushton V. The use of radiography and the apex locator in endodontic treatment within the UK: a comparison between endodontic specialists and general dental practitioners. International Endodontic Journal 2013; 46:355-364. https://doi.org/10.1111/j.1365-2591.2012.02127.x

18. Berlin V, Puriene A, Peciuliene V, Aleksejuniene J. Treatment procedures and referral patterns of general dentists in Lithuania. Medicina 2015; 51:296-301.

https://doi.org/10.1016/j.medici.2015.09.004

19. Koch M, Eriksson H, Axelsson S, Tegelberg A. Effect of educational intervention on adoption of new endodontic technology by general dental practitioners: a questionnaire survey.
International Endodontic Journal 2009; 42:313-321.

https://doi.org/10.1111/j.1365-2591.2008.01511.x

20. Locke M, Thomas M, Dummer P. A survey of adoption of endodontic nickel-titanium rotary instrumentation part 1: general dental practitioners in Wales. British Dental Journal 2013; 214(3).

https://doi.org/10.1038/sj.bdj.2013.108

21. Demant S, Markvart M, Bjorndal L. Quality-shaping factors and endodontic treatment amongst general dental practitioners with a focus on Denmark. International Journal of Dentistry 2012; Article ID 526137.

https://doi.org/10.1155/2012/526137

22. Whitworth J, Seccombe G, Shoker K, Steele J. Use of rubber dam and irrigant selection in UK general dental practice. International Endodontic Journal 2000; 33: 435-441.

https://doi.org/10.1046/j.1365-2591.2000.00329.x

23. Tosic G, Miladinovic M, Kovacevic M, Stojanovic M. Choice of root canal Irrigants by Serbian dental practitioners. Vojnosanitetski pregled 2015; 73(1):47-52.

https://doi.org/10.2298/VSP140909034T

24. Patil P, Rathore V, Hotkar C, Savgave S, Raghavendra K, Ingale P. A comparison of apical sealing ability between GuttaFlow and AH plus: An in vitro study. Journal of International Society of Preventive and Community Dentistry 2016; 6(4): 377-382. https://doi.org/10.4103/2231-0762.186794

25. H. Schilder. Cleaning and Shaping the Root canals. Dental Clinics of North America 1974; 18(2):269-96.

26. H. Schilder. Filling Root Canals in Three Dimensions. Journal of Endodontics 2006; 32(4):281-290.

https://doi.org/10.1016/j.joen.2006.02.007

\section{LIETUVOS GYDYTOJŲ ODONTOLOGŲ NAUDOJAMOS ENDODONTINĖS MEDŽIAGOS, GYDYMO METODIKOS IR POŽIŪRIS I TARPTAUTINI ENDODONTINIO GYDYMO PROTOKOLĄ. AR AMŽIUS TURI ITAKOS? ANKETINIS TYRIMAS}

L. Vaitkus, M. Mackevičiūtė, E. Kelbauskas

Raktažodžiai: anketa, dantų šaknų kanalų gydymas, endodontinis gydymas, endodontinio gydymo reikalavimai, gydytojas odontologas.

Santrauka

Tikslas. Surinkti ir ịvertinti duomenis apie Lietuvos gydytojų odontologų naudojamas endodontines medžiagas, metodikas ir požiūrị bei jų atitikimą tarptautiniam endodontinio gydymo protokolui, atsižvelgiant, ar klinikinè patirtis turi tam reikšmę.

Medžiagos ir metodika. Duomenims surinkti buvo išdalinta 350 anketų keturiuose didžiuosiuose Lietuvos miestuose (Vilniuje, Kaune, Klaipėdoje, Utenoje). Klausimynus sudarè bendriniai klausimai apie respondentų lyti, klinikinès praktikos trukmę, naudojamas medžiagas ir metodikas endodontinio gydymo metu ir kt. Duomenys buvo analizuoti SPSS 22.0 sistema (Statistical Package for Social Science 22 for Windows) 


\section{2}

Rezultatai. Iš viso buvo sugrąžintos 134 (38,3 \%) anketos. Analizuojamos tik tos anketos, kurių visi klausimai atsakyti ir kurios buvo užpildytos gydytojų odontologų, atliekančių endodontini gydymą (109 or $31,1 \%)$. Respondentai, neatitikę kriterijų, nedalyvavo tyrime. $77,6 \%$ jaunesnio amžiaus odontologu (turintys 10 ir mažiau metu klinikinès patirties) naudoja koferdamo sistemą endodontinio gydymo metu, ir tik 30,6 \% vyresnès kartos gydytojų (turinčių daugiau nei 10 metų klinikinès patirties) atlieka procedūrą naudojant šią izoliacinę sistemą. Žingsnio atgal metodika buvo labiausiai populiari taro jaunesnès kartos gydytojų, o NiTi sukamieji instrumentai ir vainiko - žemyn technika (rankiniais instrumentais) - populiaresnès tarp didesnę klinikinę patirtị turinčių odontologų. K-tipo dildès yra populiariausi endodontiniai instrumentai. Rentgenologinis tyrimas dažniausiai atliekamas prieš procedūrą ir po dantų šaknų kanalų gydymo. Šalta lateralinė kondensacija, nau- dojant cinko oksido eugenolio pagrindo silerį - dažniausiai taikoma plombavimo metodika, o natrio hipochlorito tirpalas dantų šaknų kanalų gydymo metu - pirmo pasirinkimo irigacinis tirpalas.

Išvados. Rezultatai parodè, kad jaunesnès kartos gydytojai odontologai yra arčiau endodontinio gydymo protokolo principų, tačiau laikosi ne visų jo aspektų.

Adresas susirašinèti: miglemackeviciute@gmail.com

Gauta 2017-05-05 